ISSN: 2224-0616

Int. J. Agril. Res. Innov. Tech. 11(1): 26-28, June 2021

DOI: https://doi.org/10.3329/ijarit.v11i1.54463
OPEN 2 ACCESS

Available online at https://ijarit.webs.com https://www.banglajol.info/index.php/IJARIT

\title{
Evaluation of durum wheat varieties for yield and yield related traits in highland areas of southern Ethiopia
}

\author{
S. Shibeshi* and D. Kassa \\ Received 7 February 2021, Revised 31 May 2021, Accepted 23 June 2021, Published online 30 June 2021
}

\begin{abstract}
A B S T R A C T
Durum wheat productivity in Ethiopia is hindered by different factors mainly lack of improved adapted varieties for specific locations. This experiment was done to identify the most performing durum wheat varieties in the tested environment. The average productivity of the tested genotypes were evaluated at two locations (Alicho and Analimo) using randomized complete block design with four replication for two consecutive years (2016 and 2017). The experimental material consists of seven improved durum wheat genotypes. The Combined analysis of variance showed significant $(P<0.05)$ difference among tested genotypes on collected parameter indicating the presence of adequate variability. The highest average grain yield recorded was $4446 \mathrm{~kg} \mathrm{ha}^{-1}$ from Hitosa variety while the lowest obtained was $3634 \mathrm{~kg} \mathrm{ha}^{-1}$ from Denbi variety. Grain yield had strong positive correlations $(P<0.01)$ with plant height, number of seed spike $\mathrm{e}^{-1}$ and biomass.
\end{abstract}

Keywords: Variety, Grain yield, Durum wheat, Genetic variability.

Southern Agricultural Research Institution, Worabe Agricultural Research Center, Worabe, Ethiopia.

*Corresponding author's email: shibeshisolomon23@gmail.com (Solomon Shibeshi)

Cite this article as: Shibeshi, S. and Kassa, D. 2021. Evaluation of durum wheat varieties for yield and yield related traits in highland areas of southern Ethiopia. Int. J. Agril. Res. Innov. Tech. 11(1): 26-28. https://doi.org/10.3329/ijarit.v11i1.54463

\section{Introduction}

Wheat (Triticum spp.) cultivation reaches far back into history. It was one of the primary domesticated food crops and for 8000 years, it has been the basic staple food of the major civilizations of Europe, West Asia and North Africa. Today, the crop is grown on a huge land area than any other commercial crop and remains to be the most important food grain source for humans. Its production became prior to all crops, including rice, maize and potatoes (Curtis, 2002).

Most of the tetraploid wheat varieties, grown in Ethiopia are landraces consisting of a large number of different genetic lines. Purseglove (1975) reported the presence of genetic diversity of durum wheat in Ethiopia and Zohary (1970) identified Ethiopia as the center of origin for tetraploid wheat. However, the absence of ancestral forms and wild relatives ruled-out Ethiopia as the center of origin of cultivated wheat (Pecetti et al., 1992).

In spite of cultivating wheat in most parts of Ethiopia, the country is not self-sufficient in production and consequently a large quantity of durum wheat is imported every year. The domestic average yield of the crop in the country, which is $1379 \mathrm{~kg} \mathrm{ha}^{-1}$, is $24 \%$ below the average of African yields and $48 \%$ below that of the world's (FAO, 1994). Food production and eventually human survival depends on land, soil and water and on the methods used to exploit these resources in a sustainable manner. The regions of highest food production have been those with favorable climatic conditions, relatively fertile soils and an adequate supply of water, among others (Getachew, 2004). The major breeding objective in durum wheat is to create new improved genotypes with features that contribute to greater yield potential, increased yield stability and improved product quality (Poehlman and Sleper, 1995).

In Ethiopia, there are different varieties of improved durum wheat varieties released from research center. However, seed of this cultivar and other cultivars were multiplied and distributed all over the region on limited scale by the research centers and some farmers. The objective of this study was to select the most adaptable durum wheat varieties for highland areas and to select the varieties that have good agronomic performance to the area.

\section{Materials and Methods}

\section{Experimental design and methods}

Seven durum wheat varieties were evaluated at two locations (Alicho and Analimo). The varieties were released from federal agricultural research centers (Deberzeit Agricultural Research Center). 
The experiment was conducted using randomized complete block design with four replications in the two main cropping seasons in the years of 2016 and 2017. The size of experimental plot is $1.2 \mathrm{~m} \times 2.5 \mathrm{~m}\left(3 \mathrm{~m}^{2}\right)$, with six rows which are 20 $\mathrm{cm}$ apart each other. Recommended seed rate (125 $\left.\mathrm{kg} \mathrm{ha}^{-1}\right)$ and fertilizer rate (100 $\mathrm{kg} \mathrm{ha}^{-1}$ urea and $100 \mathrm{~kg}$ NPS) were used in the experiment. The whole amount of NPS was applied at planting while urea was split in to half at planting and the remaining half at tillering stage. All agronomic managements were applied equally as per the recommendation.

\section{Data collected}

Data on plant height, spike length and number of tillers per plant were recorded from five randomly taken plants from the central four rows, which were tagged ahead of heading. Data for the rest of the characters were recorded from the whole plots.

\section{Statistical analysis}

A significance test was adopted by analysis of variance (ANOVA) for Randomized Complete Block Design. The ANOVA was carried out using the General Linear Model of the SAS Version 9.4 procedure. For factors showing significant effects, mean comparisons were made using Least Significance Difference (LSD) at $5 \%$ level of significance.

\section{Results and Discussions}

There were highly significant differences $(P<0.05)$ among tested varieties for many of the characters considered, revealing the existence of substantial amount of variation among the varieties (Table 1). This is in agreement with the findings of Getachew et al. (1993), indicating that Ethiopian durum wheat germplasm exhibits tremendous genetic variability.
This suggested that the magnitude of differences in genotypes was sufficient to provide some scope for selecting genotypes to improve.

The varieties showed significant difference $(P<0.05)$ on plant height and spike length but they were not significantly different on number of productive tillers. The average plant height ranged from $74.8 \mathrm{~cm}$ to $94.0 \mathrm{~cm}$. The highest average plant height was recorded from Asassa variety $(94.0 \mathrm{~cm})$ while the smallest plant height was recorded from Mangudo $(74.8 \mathrm{~cm})$ variety. The average spike length recorded among the genotype ranged from $4.5 \mathrm{~cm}$ to $6.7 \mathrm{~cm}$. The maximum average spike length recorded from Ude variety $(2.7 \mathrm{~cm})$.

Beside plant height and spike length, the tested varieties were significant difference on above ground biomass and grain yield. The average above ground biomass recorded ranged from 5,300 to $10,050 \mathrm{~kg} \mathrm{ha}^{-1}$. The maximum above ground biomass recorded from Ude variety $\left(10,050 \mathrm{~kg} \mathrm{ha}^{-1}\right)$ while the minimum were recorded from Yerer variety $\left(5,300 \mathrm{~kg} \mathrm{ha}^{-1}\right)$. The average grain yield recorded ranged from 3634.8 to $4446.3 \mathrm{~kg} \mathrm{ha}^{-1}$. The maximum grain yield recorded from Hitosa variety (4446.3 $\mathrm{kg} \mathrm{ha}^{-1}$ ) while the minimum were recorded from Denbi variety $\left(3634.8 \mathrm{~kg} \mathrm{ha}^{-1}\right)$.

There was significant difference among genotype and location by genotype interaction on grain yield (Table 2). The yield difference across location may come from the adaptability of a particular genotype in specific area and difference in rainfall patterns and due to soil nature of the study area. The tested varieties were well performed at Alicho as compared to Analimo site. At Alicho Ude, Hitosa and Mangudo ranked $1^{\text {st }}, 2^{\text {nd }}$ and $3^{\text {rd }}$ with grain yield of $4795.0,4472.0$ and $4289.0 \mathrm{~kg} \mathrm{ha}^{-1}$, respectively while at Analimo Hitosa, Makiya and Asassa ranked $1^{\text {st }}, 2^{\text {nd }}$ and $3^{\text {rd }}$ with grain yield of $4419.0,4224.0$ and $3945.0 \mathrm{~kg}$ $\mathrm{ha}^{-1}$, respectively.

Table 1. The Mean performance of tested genotype on collected traits for the two locations.

\begin{tabular}{|lcccccc|} 
Varieties & PH $(\mathrm{cm})$ & SL $(\mathrm{cm})$ & TPP & BM $\left(\mathrm{kg} \mathrm{ha}^{-1}\right)$ & GY $\left(\mathrm{kg} \mathrm{ha}^{-1}\right)$ & HI \\
\hline Makiya & $81.4 \mathrm{~b}$ & $4.9 \mathrm{~b}$ & $2.5 \mathrm{a}$ & $8500 \mathrm{~b}$ & $4112.6 \mathrm{ab}$ & $0.5 \mathrm{~b}$ \\
\hline Mangudo & $74.8 \mathrm{~d}$ & $4.5 \mathrm{~b}$ & $2.6 \mathrm{a}$ & $8150 \mathrm{bc}$ & $3705.9 \mathrm{~b}$ & $0.5 \mathrm{~b}$ \\
\hline Asassa & $94.0 \mathrm{a}$ & $4.6 \mathrm{~b}$ & $2.5 \mathrm{a}$ & $9350 \mathrm{a}$ & $3809.3 \mathrm{ab}$ & $0.5 \mathrm{~b}$ \\
\hline Ude & $77.5 \mathrm{~cd}$ & $6.7 \mathrm{a}$ & $2.7 \mathrm{a}$ & $10050 \mathrm{a}$ & $4132.9 \mathrm{ab}$ & $0.5 \mathrm{~b}$ \\
\hline Yerer & $78.2 \mathrm{bcd}$ & $4.7 \mathrm{~b}$ & $2.6 \mathrm{a}$ & $5300 \mathrm{c}$ & $3709.6 \mathrm{~b}$ & $0.9 \mathrm{a}$ \\
\hline Denbi & $78.5 \mathrm{bc}$ & $5.0 \mathrm{~b}$ & $2.6 \mathrm{a}$ & $5900 \mathrm{c}$ & $3634.8 \mathrm{~b}$ & $0.9 \mathrm{a}$ \\
\hline Hitosa & $76.8 \mathrm{~cd}$ & $4.7 \mathrm{~b}$ & $2.6 \mathrm{a}$ & $7750 \mathrm{bc}$ & $4446.3 \mathrm{a}$ & $0.7 \mathrm{ab}$ \\
\hline LSD (5\%) & 3.7 & 0.6 & 0.3 & 2993.2 & 671.2 & 0.2 \\
\hline CV $(\%)$ & 4.8 & 8.2 & 10.1 & 16.8 & 14.9 & 18.3 \\
\hline
\end{tabular}

Key: $-P H=$ Plant height,$S L=$ Spike length,$T P P=$ Tillers per plant, $B M=$ biomass, $G Y=$ Grain yield, $H I=$ Harvest index, $L S D=$ least significant difference, and $C V=$ coefficient of variation Mean value within the column with different letter are significantly different at $p<0.05$. 
Table 2. ANOVA for yield trait.

\begin{tabular}{|lccccc|} 
Source of Variation & DF & SS & MS & F Value & P Value \\
\hline Replication & 3 & 1380603 & 460201 & & \\
\hline Location & 1 & 1861319 & 1861319 & 5.38 & 0.0258 \\
\hline Genotype & 6 & 4330848 & 721808 & 2.08 & 0.0172 \\
\hline Location*Genotype & 6 & 5094454 & 849076 & 2.45 & 0.0115 \\
\hline Error & 39 & 13500000 & 346263 & & \\
\hline
\end{tabular}

Most of the collected agronomic characters showed positive correlation against grain yield. Spike plant ${ }^{-1}$, biomass had strong correlation with grain yield with correlation coefficient value of 0.52 and 0.66 respectively (Table 3 ). Similar results were reported by Del Blanco et al. (2001)

Table 3. Correlation among traits. and Ozturk and Aydin (2004), who showed significant positive correlations between spike plant $^{-1}$, biomass and grain yield in hexaploid wheat. There was negative correlation among plant height and number of tiller.

\begin{tabular}{|lcllll|}
\hline \multicolumn{7}{c}{ PH } & SL & NT & BM & YLD & HI \\
\hline PH & & & & \\
\hline NT & 0.0207 & & & \\
\hline BM & 0.0636 & $0.4778^{*}$ & & & \\
\hline YLD & $0.4112^{*}$ & $0.4961^{*}$ & $0.4019^{*}$ & & \\
\hline HI & $0.3221^{*}$ & $0.523^{* *}$ & $0.4604^{*}$ & $0.6578^{* *}$ & $0.377^{*}$ \\
\hline
\end{tabular}

* and ${ }^{*}$ Significant at the $5 \%$ and $1 \%$ levels of probability, respectively.

\section{Conclusion}

Shortage of improved varieties accessibility and limited studies in the study area was one of the main problems. This study generally indicated that there is an opportunity in selection of superior varieties on agronomic trait specially grain yield among tested durum wheat genotypes through direct selection at the study locations as short term strategy rather than a lengthy crossing program.

It was found that there is $22.34 \%$ boost of yield for using Hitosa variety (high yielder) as compared to Denbi variety (low yielder) at the study area. Variety Hitosa were well performed at both locations and Ude performed well at Alicho. These varieties can be used for wheat production and seed system program at both locations.

Funding: This research was funded by Southern Agricultural Research Institution.

Acknowledgments: Authors acknowledge the support of worabe agricultural research center staffs, Mr. Muluneh mekiso for the facilitation of work by providing the necessary materials required for fieldwork.

Conflicts of Interest: The authors declare no conflict of interest. The funders had no role in the design of the study; in the collection, analyses, or interpretation of data; in the writing of the manuscript, or in the decision to publish the results.

\section{References}

Curtis, B.C. 2002. Wheat in the world. In: Curtis B.C., Rajaram S. and McPherson H.G. Eds. Bread wheat Improvement and Production,
Plant Production and Protection Series 30, FAO, Rome. pp. 1-18.

Del Blanco, I.A., Rajaram, S. and Kronstad, W.E. 2001. Agronomic potential of synthetic hexaploid wheat derived populations. Crop Sci. 41(3): 670-676.

https://doi.org/10.2135/cropsci2001.413670x

FAO. 1994. Production Year Book 1994. Rome, Italy.

Getachew, B., Tesemma, T. and Mitiku, D. 1993. Variability and correlation studies in durum wheat in Alem Tena, Ethiopia. Rachis News Letter. 12: 38-40.

Getachew, F. 2004. Soil characterization and bread wheat response to $\mathrm{N}$ and $\mathrm{P}$ fertilization on nitosol at Ayehu Research Substation in North Western Ethiopia.

Ozturk, A. and Aydin, F. 2004. Effects of water stress at various growth stages on some quality characteristics of winter wheat. Agron. Crop. Sci. 190: 93-99. https://doi.org/10.1046/j.1439037X.2003.00080.x

Pecetti, L., Annicchiaricpo, P. and Damaniaa, A.B. 1992. Biodiversity in a germplasm collection of durum wheat. Euphytica. 60: 229-238. https://doi.org/10.1007/BFooo39403

Poehlman, J.M. and Sleper, D.A. 1995. Breeding Field Crops (4 ${ }^{\text {th }}$ Edition). Iowa State University Press. Iowa, USA. pp. 259-261.

Purseglove, J.W. 1975. Tropical Crops; Monocotyledons. John Wiley \& Sons, Inc., New York, USA. pp. 287-291.

Zohary, D. 1970. Centers of diversity and centers of origin. In: Frankel $\mathrm{OH}$, Bennet $\mathrm{E}$ (eds) Genetic Resources in Plants-their exploration and conservation, Blackwell: Oxford. pp. 33-42. 